\title{
Optimization of vacuum infiltration before blanching of black cherry tomatoes (Solanum lycopersicum cv. OG) using response surface methodology
}

\author{
1,2,3*Ha, H.T.N. and ${ }^{3}$ Thuy, N.M. \\ ${ }^{1}$ Department of Food Technology, Faculty of Agriculture and Natural Resources, An Giang University, An \\ Giang, Vietnam, \\ ${ }^{2}$ Vietnam National University Ho Chi Minh City, Vietnam \\ ${ }^{3}$ College of Agriculture, Can Tho University, Vietnam
}

\begin{abstract}
Article history:
Received: 9 March 2020

Received in revised form: 30

March 2020

Accepted: 1 April 2020

Available Online: 24 April

2020
\end{abstract}

Keywords:

Optimization,

Vacuum infiltration,

Blanching,

Black cherry tomatoes,

Peroxidase,

Bioactive compounds

DOI:

https://doi.org/10.26656/fr.2017.4(4).100

\begin{abstract}
Blanching is a necessary stage in fruits and vegetable processing to inactivate enzymes and destroy microorganisms but, can degrade heat-sensitive nutrients. Therefore, in this study, the vacuum infusion of black cherry tomatoes (Solanum lycopersicum cv. OG) was optimized to obtain the highest blanching efficiency while maintaining maximum levels of bioactive compounds. The experiment was designed using the Response Surface Methodology (RSM) with two factors of vacuum level $(529-671 \mathrm{mmHg}$ ) and treatment time (16-24 mins). The research found that the optimum vacuum level and processing time, $620.70 \mathrm{mmHg}$ and $22.27 \mathrm{mins}$, respectively, gave the best results with the weight gain $2.33 \%$ after vacuum infiltration, the remaining peroxidase activity $12.24 \% \mathrm{db}$ and the pectin content $36.55 \% \mathrm{db}$ after blanching at $90^{\circ} \mathrm{C}$ for $60 \mathrm{~s}$. Meanwhile, the remaining peroxidase activity and pectin content were $30.98 \% \mathrm{db}$ and $16.86 \% \mathrm{db}$, respectively for the $1^{\text {st }}$-control sample (not vacuum treated and blanched at $90^{\circ} \mathrm{C}$ for $60 \mathrm{~s}$ ). The content of lycopene, vitamin $\mathrm{C}$ and total phenolic in vacuum infiltrated sample $(66.32 \mathrm{mg} / 100 \mathrm{~g} \mathrm{db}$, $0.762 \% \mathrm{db}, 6.42 \mathrm{mg} \mathrm{GAE} / \mathrm{g} \mathrm{db}$, respectively) was lower than the $1^{\text {st }}$-control $(73.82$ $\mathrm{mg} / 100 \mathrm{~g} \mathrm{db}, 1.01 \% \mathrm{db}, 6.55 \mathrm{mg} \mathrm{GAE} / \mathrm{g} \mathrm{db}$, respectively) but higher than the $2^{\text {nd }}$-control (not vacuum treated and blanched at $90^{\circ} \mathrm{C}$ for $80 \mathrm{~s}$ attaining equivalent remaining peroxidase activity of $12.51 \%)(62.26 \mathrm{mg} / 100 \mathrm{~g} \mathrm{db}, 0.710 \% \mathrm{db}, 5.70 \mathrm{mg} \mathrm{GAE} / \mathrm{g} \mathrm{db}$, respectively) due to heat transfer efficiency. However, there was no difference between the samples with and without vacuum treatment at the same blanching conditions for anthocyanin content because this compound was found predominantly in outer cell layers. This suggested that the vacuum infiltration helped to inactivate the peroxidase as well as create soluble pectin more but maintain the content of bioactive compounds, especially anthocyanin.
\end{abstract}

\section{Introduction}

'Black' or 'purple' cherry tomatoes are subspecies of Solanum lycopersicum (Zhang et al., 2018) and exhibit a dirty purplish-brown colour on their skin (Mes et al., 2008). They are rich in bioactive compounds (lycopene $54.20 \pm 0.94 \mathrm{mg} / 100 \mathrm{~g}$ dried-weight, $\beta$-carotene $3.75 \pm 0.07$ $\mathrm{mg} / 100 \mathrm{~g}$ dried-weight) (Choi et al., 2014). Lycopene is the most abundant (about $80-90 \%$ ) and the highest antioxidant natural carotenoid found in tomatoes (Alda et al., 2009). Epidemiological studies have shown that this red pigment has the potential to reduce the risk of chronic diseases, most notably prostate cancer (Ford and Erdman, 2012). Lycopene also plays an important role in the prevention of cardiovascular disease (Mordente et al., 2011). Min and Min (2014) found that consuming a large quantity of lycopene-abundant foods led to a lower risk of mortality from Alzheimer's disease in adults. Kaur et al. (2011) also indicated that lycopene had a protective ability against oxidative stress, which is beneficial in treating Parkinson's disease and other neurological abnormalities. In addition to carotenoids, tomatoes are good for other antioxidant compounds such as vitamin $\mathrm{C}$ and phenolics which also inhibit reactive oxygen species causing many dangerous diseases (Ilahy et al., 2009). It has been noticed that the content of phenolic compounds and carotenoid pigments, particularly lycopene in black cherry tomatoes are higher than some red tomato varieties (Zhang et al., 2018). Especially, black cherry tomatoes also can produce a 
phytochemical of anthocyanin predominantly in the skin (Li et al., 2011). Anthocyanin has been proven to be associated with many health benefits, reduces cancer cell proliferation, protects against cardiovascular disease, prevents obesity and diabetes (Lila, 2004).

Because of their health benefits, black cherry tomatoes can be used as fresh vegetables or processed into popular liquid products such as puree, ketchup and sauce (Zhang et al., 2018). Blanching of raw material is a necessary stage in the processing of these products to inactivate enzymes and destroy microorganisms that cause undesirable organoleptic and nutritional changes thereafter (Xiao et al., 2014). The conversion from protopectin into soluble pectin also took place under the effect of high temperature during blanching (RamosAguilar et al., 2015). This pectin ingredient presenting in tomato sauces and similar products helps to create a characteristic viscous texture (Mesbahi et al., 2005). However, like other thermal treatment processes, blanching can lead to a significant loss of heat-sensitive nutritional components.

On the other hand, vacuum infiltration technology was found to increase the thermal conductivity (up to 24\%) (Martínez-Monzó et al., 2000), so that it has occasionally been applied to some foods before thermal processing such as blanching or pasteurizing to improve heat transfer capacity and limit thermal damages in the product (Saurel, 2000). This result was mainly explained by the replacement of gases inside the fruit spores by the liquid, which reduced the thermal resistance associated with the void fraction (Saurel, 2000).

Therefore, this study carried out the optimization of the vacuum infiltration of black cherry tomatoes to find the optimal parameters which improved the efficiency of the subsequent blanching process, that means, to inactivate the peroxidase and convert protopectin to soluble pectin as much as possible but prevent the destruction of bioactive compounds due to heat, especially anthocyanin in the outer skin of fruits.

\section{Materials and methods}

\subsection{Tomato fruits}

Black cherry tomato (cv. OG) seeds were provided by the F1508 seed store (Ho Chi Minh City, Vietnam) and grown in a garden house at Nam Long farm, Vinh Long province, Vietnam. Tomatoes were harvested at full ripeness (32 days after fruit formation). All fruits with diseases and defects were removed. Fruits were packed into perforated PVC and then cardboard boxes. They were transported to the Food Technology Laboratory of Can Tho University, Vietnam within one hour. Tomatoes were washed and then dipped into the water which was aerated with ozone for 15 mins by a 2nozzle ozone generator (Z755, Vietnam, ozonegenerating of $80.4 \mathrm{mg} / \mathrm{h}$, the sample weight of $1500 \mathrm{~g}$, the ratio of fruits and water was 1:2). Then, fruits were drained and used for the experiment.

\subsection{Experimental design}

The experiment was designed by the Portable Statgraphics Centurion software (version 15.2.11.0, U.S.A) with two factors of vacuum level $\left(\mathrm{X}_{1}\right)$ and treatment time $\left(\mathrm{X}_{2}\right)$. The Response Surface Methodology (RSM) with a model of Central Composite Design (CCD) was applied. A preliminary study was carried out for determining a narrower range of two factors before designing the optimization experiment. Accordingly, a wide range of vacuum level $(300-700 \mathrm{mmHg})$ and treatment time (5-25 mins) was examined and as a result, the study ranges were chosen as $550-650 \mathrm{mmHg}$ and 17 $23 \mathrm{~min}$. The actual and coded values of each parameter were presented in Table 1. Each factor was encoded with five levels: $-1.414,-1$ (low), 0 (central), +1 (high) and $+1,414$. Total samples were 14 , including six replications of the central point to obtain a good estimation of errors. Each sample was $500 \mathrm{~g}$ tomatoes and a ratio of material and distilled water was 1:1. The infiltration process was carried out in vacuum equipment (Rocker 400, Laftech, Australia). The mixture after vacuum treatment was brought to the atmospheric condition and kept for another $15 \mathrm{~min}$. After that, fruits were blanched in hot water at $90^{\circ} \mathrm{C}$ for $1 \mathrm{~min}$ and cooled quickly by tap water. A control sample was conducted with no vacuum treatment and blanching at $90^{\circ} \mathrm{C}$ for $60 \mathrm{~s}$ while another control was also not vacuum infiltrated but blanched at $90^{\circ} \mathrm{C}$ until the peroxidase activity is equivalent to the value of the optimal vacuum treatment sample.

The weight gain of samples after vacuum infiltration was determined. Then the remaining peroxidase activity, content of pectin and bioactive compounds of samples after blanching were also evaluated.

\subsection{Analytical methods}

\subsubsection{Weight gain}

Weight gain of fruits was calculated according to equation 1 . Where $W_{o}$ is the weight of tomatoes at the beginning $(\mathrm{g}) ; W_{i}$ is the weight of tomatoes after vacuum infiltration $(\mathrm{g})$.

$$
\text { Weight gain }(\%)=\frac{W_{i}-W_{o}}{W_{o}} \times 100
$$

\subsubsection{Peroxidase (POD) activity}

The peroxidase activity was determined by the colourimetric method based on reaction with guaiacol (Morales-Blancas et al., 2002; Goncalves et al., 2007) 
with some modifications. Tomato puree $(20 \mathrm{~g})$ was extracted with $100 \mathrm{~mL}$ of $1 \mathrm{M} \mathrm{NaCl}$ solution for 10 mins on a shaker (SK600, Lab Companion, Korea) at a speed of $180 \mathrm{rpm}$. The mixture was then separated by a centrifuge (Z323K, Hermle Labortechnik $\mathrm{GmbH}$, Germany) at $7000 \mathrm{x} g$ for 10 mins. The substrate solution was prepared daily by mixing $0.1 \mathrm{~mL}$ guaiacol (99.5\%), $0.1 \mathrm{~mL} \mathrm{H}_{2} \mathrm{O}_{2}(30 \%)$ and $99.8 \mathrm{~mL}$ potassium phosphate buffer $(0.1 \mathrm{M})$. The supernatant $(0.12 \mathrm{~mL})$ was mixed with $3.48 \mathrm{~mL}$ of substrate solution and the absorbance increase was recorded after $20 \mathrm{mins}$ at $470 \mathrm{~nm}$ by a Spectrophotometer UV-VIS (722N, Inesa, China) using a blank prepared with $0.12 \mathrm{~mL}$ distilled water and $3.48 \mathrm{~mL}$ POD substrate solution. The remaining enzyme activity $\left(U_{t}\right)$ was expressed as a percentage of the total initial activity $\left(U_{o}\right)$ and calculated by equation 2 .

$$
\text { Peroxidase }(\%)=\frac{\mathrm{U}_{\mathrm{t}}}{\mathrm{U}_{\mathrm{o}}} \times 100
$$

\subsubsection{Pectin content}

The pectin content was determined by the pectate calcium method (Mai, 2005). Tomato puree $(50 \mathrm{~g})$ was filled to a volume of $100 \mathrm{~mL}$ with distilled water and filtered through a filter paper. The filtrate $(20 \mathrm{~mL})$ was mixed with $100 \mathrm{~mL}$ of $0.1 \mathrm{~N} \mathrm{NaOH}$ solution. The saponification of pectin was carried out for $7 \mathrm{hrs}$. The mixture was added $50 \mathrm{~mL}$ of $0.1 \mathrm{~N} \mathrm{CH}_{3} \mathrm{COOH}$ solution, left for 5 mins and then added $50 \mathrm{~mL}$ of $1 \mathrm{~N} \mathrm{CaCl}_{2}$ solution. After $1 \mathrm{hr}$, the sample was boiled for $5 \mathrm{mins}$ and then filtered through a filter paper. The filter paper containing the precipitate was dried at $105^{\circ} \mathrm{C}$ to a constant weight. The pectin content was calculated using equation 3 . Where $P$ is the weight of precipitate $(\mathrm{g}), 0.92$ is the conversion coefficient from calcium pectate to pectin, $m$ is the weight of the sample ( $\mathrm{g}$ ).

$$
\text { Pectin }(\%)=\frac{\mathrm{P} \times 0.92}{20} \times \frac{100}{\mathrm{~m}} \times 100
$$

\subsubsection{Anthocyanin content}

The anthocyanin content was determined by the $\mathrm{pH}$ differential method (Lee et al., 2005) with some modifications. Tomato puree $(5 \mathrm{~g})$ was filled to a volume of $50 \mathrm{~mL}$ with ethanol/water (1/1) solvent containing $1 \%$ $\mathrm{HCl}$ and extracted for 60 mins. The mixture was then separated by a centrifuge at $7000 \mathrm{x} g$ for $10 \mathrm{mins}$. The supernatant was diluted with two buffers of $\mathrm{pH} 1.0$ and 4.5 and read the absorbance at both 520 and $700 \mathrm{~nm}$ versus a blank of distilled water. The anthocyanin content was calculated as cyanidin-3-glucoside equivalent (equation 4$)$. Where $A$ is $\left(\mathrm{A}_{520 \mathrm{~nm}}-\mathrm{A}_{700 \mathrm{~nm}}\right) \mathrm{pH}$ $1.0-\left(\mathrm{A}_{520 \mathrm{~nm}}-\mathrm{A}_{700 \mathrm{~nm}}\right) \mathrm{pH} 4.5, M$ is $449.2 \mathrm{~g} / \mathrm{mol}$ for cyanidin-3-glucoside, $k$ is the dilution factor, $l$ is the pathlength $(\mathrm{cm}), \quad \varepsilon$ is 26900 - molar extinction coefficient for cyanidin-3-glucoside $\left(\mathrm{L} \cdot \mathrm{mol}^{-1} \cdot \mathrm{cm}^{-1}\right), V$ is the volume of extract $(\mathrm{mL}), m$ is the weight of the sample (g).

$$
\text { Anthocyanin }(\mathrm{mg} \mathrm{CE} / 100 \mathrm{~g})=\frac{\mathrm{A} \times \mathrm{M} \times \mathrm{k} \times \mathrm{V}}{\mathrm{m} \times \varepsilon \times \mathrm{l}} \times 100 \times 1000
$$

\subsubsection{Lycopene content}

The lycopene content was determined by the low volume hexane extraction method (Fish et al., 2002; Davis et al., 2003). Tomato puree ( $0.6 \mathrm{~g})$ was mixed with $5 \mathrm{~mL}$ of acetone containing $0.05 \%$ butylated hydroxytoluene, $5 \mathrm{~mL}$ of $95 \%$ ethanol, $10 \mathrm{~mL}$ of hexane and extracted for $15 \mathrm{~min}$ on a shaker at a speed of 180 $\mathrm{rpm}$. The mixture was then added $3 \mathrm{~mL}$ of deionized water and shook for another $5 \mathrm{~min}$. The vial was left for $5 \mathrm{~min}$. The absorbance of the supernatant layer was read at $503 \mathrm{~nm}$ against a blank of hexane. The lycopene content was determined using equation 5 . Where $A_{503}$ is the absorbance of the extract at $503 \mathrm{~nm}, m$ is the weight of the sample (g).

$$
\text { Lycopene }(\mu \mathrm{g} / \mathrm{g})=\frac{A_{503} \times 31.2}{\mathrm{~m}}
$$

\subsubsection{Vitamin $C$ content}

The vitamin $\mathrm{C}$ content was determined by the titration method (Lam et al., 2004). Tomato puree (10 g) was filled to a volume of $100 \mathrm{~mL}$ with $5 \% \mathrm{HCl}$ solution and filtered through a filter paper. The filtrate $(10 \mathrm{~mL})$ was added 5 drops of the $1 \%$ starch solution and titrated with the $0.001 \mathrm{~N} \mathrm{KIO}_{3} / \mathrm{KI}$ solution until the blue-black colour appears. For the control, the sample extract was replaced by the $1 \% \mathrm{HCl}$ solution. The vitamin $\mathrm{C}$ content was calculated using equation 6 . Where $a$ and $b$ is the volume of $0.001 \mathrm{~N} \mathrm{KIO}_{3} / \mathrm{KI}$ solution used for titration the extract and the control, respectively $(\mathrm{mL}), 100$ is the volume of extract $(\mathrm{mL}), 0.088$ is the weight of ascorbic acid corresponds to $1 \mathrm{~mL}$ of $0.001 \mathrm{~N} \mathrm{KIO}_{3} / \mathrm{KI}$ solution $(\mathrm{mg}), m$ is the weight of the sample $(\mathrm{g})$.

$$
\operatorname{Vitamin~} \mathrm{C}(\mathrm{mg} \%)=\frac{(\mathrm{a}-\mathrm{b}) \times 0.088 \times 100}{10} \times \frac{100}{\mathrm{~m}}
$$

\subsubsection{Total phenolic content}

The total phenolic content was determined using Folin-Ciocalteu reagent (Teixeira et al., 2013) with some modifications. Tomato puree $(5 \mathrm{~g})$ was filled to a volume of $50 \mathrm{~mL}$ with $95 \%$ ethanol and extracted for 60 mins. The mixture was then separated by a centrifuge at $7000 \mathrm{x}$ $g$ for 10 mins. The supernatant $(0.2 \mathrm{~mL})$ was added 1.0 $\mathrm{mL}$ of $10 \%$ Folin-Ciocalteu reagent, left for 5 mins and then added $1.2 \mathrm{~mL}$ of $5 \% \mathrm{Na}_{2} \mathrm{CO}_{3}$ solution. After $2 \mathrm{hrs}$, the absorbance was recorded at $750 \mathrm{~nm}$. The total phenolic content was calculated as gallic acid equivalent (equation 7). Where $C$ is the content of gallic acid derived from the standard curve $(\mathrm{mg} / \mathrm{mL}), V$ is the 
volume of extract $(\mathrm{mL}), m$ is the weight of the sample $(\mathrm{g}), k$ is the dilution factor.

$$
\text { Phenolic }(\mathrm{mg} \mathrm{GAE} / 100 \mathrm{~g})=\frac{\mathrm{C} \times \mathrm{V}}{\mathrm{m}} \times \mathrm{k} \times 100
$$

\subsection{Data analysis}

Experimental data were analyzed for Analysis of variance (ANOVA) to obtain the interaction between variables and responses and the statistical significance was evaluated by the p-value (probability) with a 95\% confidence level. The quadratic equation for predicting the optimal conditions could be expressed according to equation 8 . Where $Y$ was the predicted response, $\beta_{\mathrm{o}}$ was the constant, $\beta_{\mathrm{i}}$ was the linear coefficient, $\beta_{\mathrm{ii}}$ was the squared coefficient and $\beta_{\mathrm{ij}}$ was the interaction coefficient, $\mathrm{k}$ is the number of factors optimized. The quality of the fit polynomial model was expressed by the coefficient of determination $\mathrm{R}^{2}$. Three-dimensional plots and their respective contour plots were obtained for all responses based on the effects of two variables. Furthermore, the optimum region was identified based on the main parameters in the overlay plot.

$$
\mathrm{Y}=\beta_{\mathrm{o}}+\sum_{\mathrm{i}=1}^{\mathrm{k}} \beta_{\mathrm{i}} \mathrm{X}_{\mathrm{i}}+\sum_{\mathrm{i}=1}^{\mathrm{k}} \beta_{\mathrm{ii}} \mathrm{X}_{\mathrm{i}}^{2}+\sum_{\mathrm{i}=1}^{\mathrm{k}-1} \sum_{\mathrm{j}=2}^{\mathrm{k}} \beta_{\mathrm{ij}} \mathrm{X}_{\mathrm{i}} \mathrm{X}_{\mathrm{i}}
$$

\section{Results and discussion}

The experimental response values were represented in Table 1. The ANOVA statistical results from Table 2 showed the effects of individual terms and their interaction on the chosen response. It could be seen that both variables (vacuum level and treatment time) were significant for all responses with p-values less than 0.05 , except for anthocyanin.

The mathematical equations describing the relationship between the responses and two independent variables were established (Table 3). The coefficient of determination $\left(\mathrm{R}^{2}\right)$ gives the proportion of the total variation in the response predicted by the model, indicating the ratio of the sum of squares due to regression to the total sum of squares. A high $\mathrm{R}^{2}$ coefficient ensures a satisfactory adjustment of the quadratic model to the experimental data. For the model fitted, the $\mathrm{R}^{2}$ was more than 0.92. Guan and Yao (2008) suggested that, for a good fit of a model, $\mathrm{R}^{2}$ should be at least 0.80 . Also, the "lack of fit" which describes the variation of the data around the fitted model and is the weighted sum of squared deviations between the mean response at each factor level and the corresponding fitted value. The large p-values for "lack of fit" $(>0.05)$ showed that it was insignificant for all responses, this indicated that the model was fitted to all data (Zabeti et al., 2009). Therefore, the developed model could adequately represent the significant correlation between the variables and process responses and be applied to predict the change of responses with high accuracy.

Besides, diagnostic plots such as the estimated versus experimental values were used to judge the model satisfactoriness. These plots indicated an adequate agreement between real data and the ones obtained from the models for all responses with the correlation

\begin{tabular}{|c|c|c|c|c|c|c|c|c|c|}
\hline \multirow[b]{2}{*}{ Run } & \multirow[b]{2}{*}{ Vacuum level } & \multirow[b]{2}{*}{$\begin{array}{l}\text { Treatment } \\
\text { time }\end{array}$} & \multicolumn{7}{|c|}{ Responses } \\
\hline & & & 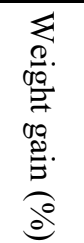 & 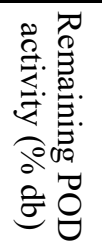 & 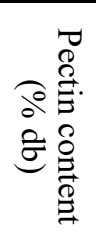 & 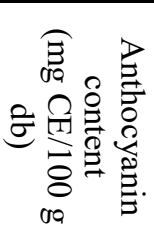 & 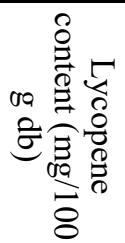 & 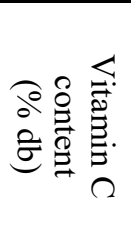 & 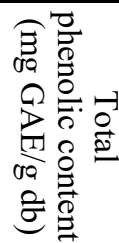 \\
\hline 1 & $550(-1)$ & $17(-1)$ & 2.04 & 15.52 & 31.92 & 63.42 & 68.47 & 0.865 & 7.42 \\
\hline 2 & $650(+1)$ & $17(-1)$ & 2.16 & 13.34 & 33.53 & 63.13 & 67.36 & 0.809 & 6.78 \\
\hline 3 & $600(0)$ & $20(0)$ & 2.29 & 12.57 & 35.68 & 62.29 & 67.41 & 0.785 & 6.56 \\
\hline 4 & $529(-1.414)$ & $20(0)$ & 2.13 & 14.51 & 33.3 & 62.63 & 68.46 & 0.875 & 7.49 \\
\hline 5 & $600(0)$ & $20(0)$ & 2.28 & 12.72 & 35.27 & 61.93 & 66.77 & 0.779 & 6.49 \\
\hline 6 & $600(0)$ & $20(0)$ & 2.3 & 12.63 & 36.09 & 62.08 & 67.19 & 0.805 & 6.43 \\
\hline 7 & $650(1)$ & $23(+1)$ & 2.31 & 12.29 & 36.51 & 63.48 & 65.92 & 0.756 & 6.46 \\
\hline 8 & $550(-1)$ & $23(+1)$ & 2.2 & 13.65 & 34.58 & 62.56 & 66.89 & 0.827 & 7.13 \\
\hline 9 & $600(0)$ & $24(+1.414)$ & 2.3 & 12.55 & 36.09 & 62.99 & 65.9 & 0.744 & 6.48 \\
\hline 10 & $671(+1.414)$ & $20(0)$ & 2.32 & 12.33 & 35.81 & 63.34 & 66.54 & 0.788 & 6.61 \\
\hline 11 & $600(0)$ & $20(0)$ & 2.29 & 12.4 & 35.54 & 62.35 & 67.47 & 0.807 & 6.62 \\
\hline 12 & $600(0)$ & $20(0)$ & 2.31 & 12.94 & 35.32 & 62.49 & 67.42 & 0.803 & 6.74 \\
\hline 13 & $600(0)$ & $20(0)$ & 2.27 & 12.79 & 36.18 & 62.54 & 66.95 & 0.787 & 6.70 \\
\hline 14 & $600(0)$ & $16(-1.414)$ & 2.11 & 13.84 & 31.94 & 63.59 & 67.82 & 0.817 & 7.10 \\
\hline
\end{tabular}

Table 1. Actual and coded values of the variables and the corresponding responses

Units of vacuum level and treatment time were $\mathrm{mmHg}$ and min, respectively. Numbers in parentheses were coded values. db - 
Table 2. ANOVA results of $\mathrm{p}$-value for responses

\begin{tabular}{lccccc}
\hline \multicolumn{1}{c}{ Responses } & $\mathrm{X}_{1}$ & $\mathrm{X}_{2}$ & $\mathrm{X}_{1}{ }^{2}$ & $\mathrm{X}_{1} \mathrm{X}_{2}$ & $\mathrm{X}_{2}{ }^{2}$ \\
\hline Weight gain (\%) & 0.0001 & 0 & 0.0006 & 0.7381 & 0.0002 \\
Remaining POD activity $(\% \mathrm{db})$ & 0.0001 & 0.0003 & 0.0011 & 0.0794 & 0.0029 \\
Pectin content $(\% \mathrm{db})$ & 0.0013 & 0.0001 & 0.0096 & 0.6938 & 0.0016 \\
Anthocyanin content $(\mathrm{mg} \mathrm{CE} / 100 \mathrm{~g} \mathrm{db})$ & 0.0582 & 0.0998 & 0.0113 & 0.0506 & 0.0021 \\
Lycopene content $(\mathrm{mg} / 100 \mathrm{~g} \mathrm{db})$ & 0.002 & 0.0009 & 0.2158 & 0.8172 & 0.1574 \\
Vitamin C content $(\% \mathrm{db})$ & 0.0007 & 0.0023 & 0.0053 & 0.5608 & 0.3539 \\
Total phenolic content $(\mathrm{mg} \mathrm{GAE} / \mathrm{g} \mathrm{db})$ & 0.0007 & 0.0071 & 0.0032 & 0.9368 & 0.0593 \\
\hline
\end{tabular}

$\mathrm{X}_{1}$ was vacuum level $(\mathrm{mmHg}), \mathrm{X}_{2}$ was treatment time (min)

Table 3. The regression equations in terms of coded variables to predict the responses

\begin{tabular}{|c|c|c|c|c|}
\hline Responses & Equations & $\mathrm{R}^{2}$ & $\mathrm{R}^{2}$ (adjusted for d.f.) & p-value (lack-of-fit) \\
\hline Weight gain (\%) & $\begin{array}{l}Y_{1}=-7.48717+0.02079 X_{1}+0.29175 X_{2}- \\
0.00002 X_{1}^{2}-0.00002 X_{1} X_{2}-0.00642 X_{2}^{2}\end{array}$ & 0.97 & 0.9513 & 0.0957 \\
\hline $\begin{array}{l}\text { Remaining POD activity } \\
(\% \mathrm{db})\end{array}$ & $\begin{array}{l}Y_{2}=126.81-0.26308 X_{1}-2.82136 X_{2}+ \\
0.00018 X_{1}^{2}+0.00137 X_{1} X_{2}+0.04492 X_{2}^{2}\end{array}$ & 0.9511 & 0.9205 & 0.0953 \\
\hline Pectin content $(\% \mathrm{db})$ & $\begin{array}{l}Y_{3}=-102.796+0.28065 X_{1}+4.40455 X_{2}^{-} \\
0.00023 X_{1}^{2}+0.00053 X_{1} X_{2}-0.10579 X_{2}^{2}\end{array}$ & 0.9751 & 0.9595 & 0.9553 \\
\hline $\begin{array}{l}\text { Anthocyanin content } \\
(\mathrm{mg} \mathrm{CE} / 100 \mathrm{~g} \mathrm{db})\end{array}$ & $\begin{array}{l}Y_{4}=158.36-0.19828 X_{1}-3.72404 X_{2}+ \\
0.00014 X_{1}^{2}+0.00202 X_{1} X_{2}+0.06141 X_{2}^{2}\end{array}$ & 0.9179 & 0.8666 & 0.8667 \\
\hline $\begin{array}{l}\text { Lycopene content } \\
(\mathrm{mg} / 100 \mathrm{~g} \mathrm{db})\end{array}$ & $\begin{array}{l}Y_{5}=94.9929-0.08795 X_{1}+0.46448 X_{2}+ \\
0.00006 X_{1}^{2}+0.00023 X_{1} X_{2}-0.02127 X_{2}^{2}\end{array}$ & 0.9411 & 0.9043 & 0.8876 \\
\hline $\begin{array}{l}\text { Vitamin } \mathrm{C} \text { content } \\
(\% \mathrm{db})\end{array}$ & $\begin{array}{l}Y_{6}=3.79047-0.01004 X_{1}+0.02860 X_{2}+ \\
0.00001 X_{1}^{2}-0.00003 X_{1} X_{2}-0.00055 X_{2}^{2}\end{array}$ & 0.9451 & 0.9108 & 0.7167 \\
\hline $\begin{array}{l}\text { Total phenolic content } \\
\text { (mg GAE/g db) }\end{array}$ & $\begin{array}{l}Y_{7}=-49.7464-0.11682 X_{1}-0.55646 X_{2}+ \\
0.00009 X_{1}^{2}-0.00005 X_{1} X_{2}+0.01308 X_{2}^{2}\end{array}$ & 0.9483 & 0.916 & 0.8209 \\
\hline
\end{tabular}

$\mathrm{X}_{1}$ was vacuum level $(\mathrm{mmHg}), \mathrm{X}_{2}$ was treatment time (min)

coefficient $\mathrm{R}^{2}>0.92$.

The response surfaces and contour plots of vacuum infiltration conditions were shown in Figure 1. The twodimensional representation of the responses on the vacuum level - treatment time plane (contour plot) showed concentrically closed curves whose centres represent the optimum conditions.

The results indicated that the vacuum impregnation process leading to an increase in fruit weight after treatment. During vacuum infiltration, gases in the food matrix expand and escape outside and after restoring atmospheric pressure, the pressure difference causes the liquid to penetrate the pores until the pressure reaches an inside and outside balance (Saurel, 2002). In general, the higher the vacuum level was and the longer the treatment time was, the greater the weight gains obtained within the experimental range. Mujica-Paz et al. (2003) evaluated the effect of vacuum pressure (135-674 mbar) and its application time (3-45 mins) on the volume of isotonic solution impregnated in slices of some fruits (mango, apple, papaya, banana, peach, melon) and reported that vacuum pressure and time had a significant effect on the volume in all fruit slices.

The general indicator used for the blanching of vegetables is the inactivation of POD that is the most heat-resistant enzyme. POD catalyzes oxidationreduction reactions. Heating for complete inactivation of POD is more than adequate to destroy the enzymes directly responsible for quality loss such as lipoxygenase, polyphenol oxidase and pectinase and often leads to over blanching (Akyol et al., 2006). A reduction in remaining POD activity after blanching at $90^{\circ} \mathrm{C}$ for $1 \mathrm{~min}$ along with an increase in vacuum level and treatment time was observed. The vacuum impregnation increased thermal conductivity because of the gas replacement (Zhao and Xie, 2004), therefore, peroxidase was more inactivated during subsequent blanching. Martínez-Monzó et al. (2000) also showed a $15-24 \%$ increase in thermal conductivity of apples submitted to vacuum impregnation. Meanwhile, the soluble pectin content which was another parameter to evaluate the effectiveness of the blanching process changed in the opposite trend. That meant the vacuum treatment improved soluble pectin content attributed to the conversion from protopectin under the effect of high temperature in blanching (Ramos-Aguilar et al., 2015).

The application of heat treatment is the most common method for stabilizing foods, because of its capacity to inactivate enzymes. However, heat can reduce the contents or bioavailability of some nutrients (Cruz et al., 2008). As can be seen from the response 


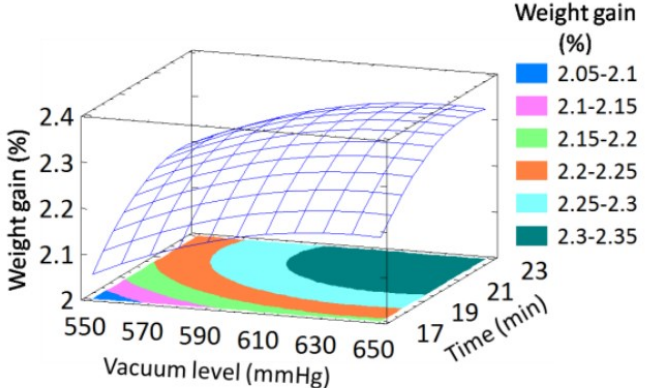

a.

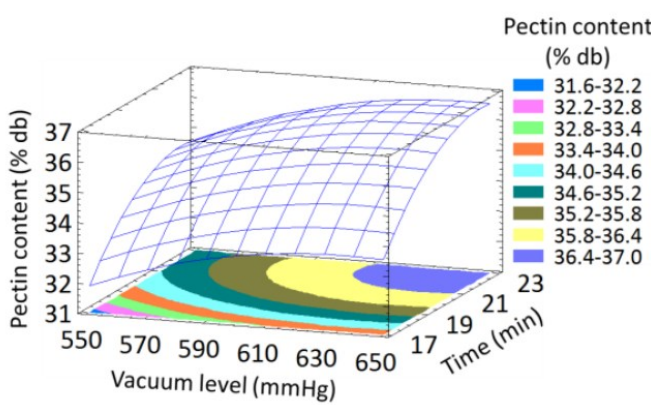

c.

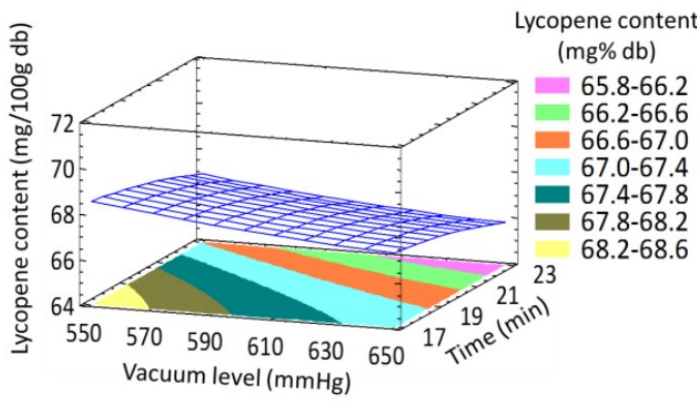

e.

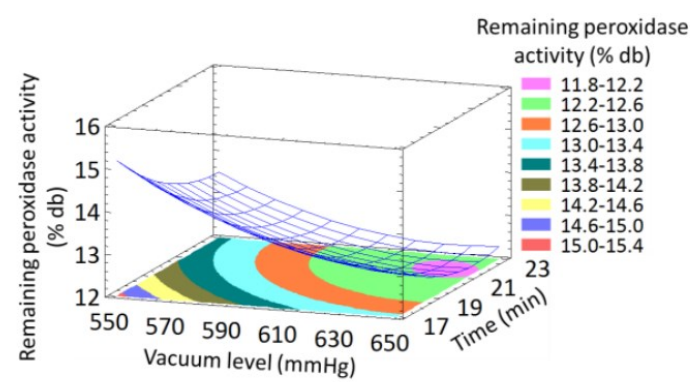

b.

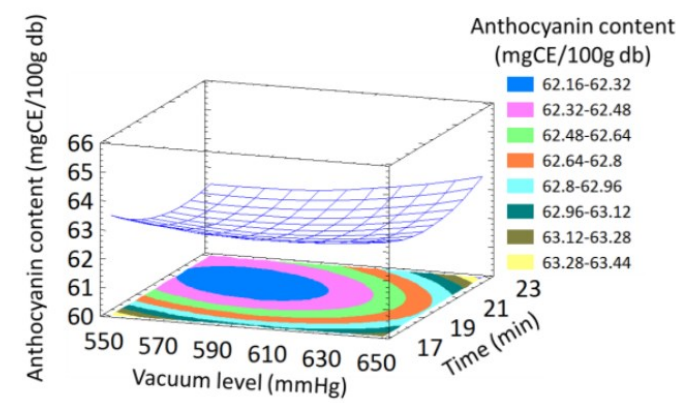

d.

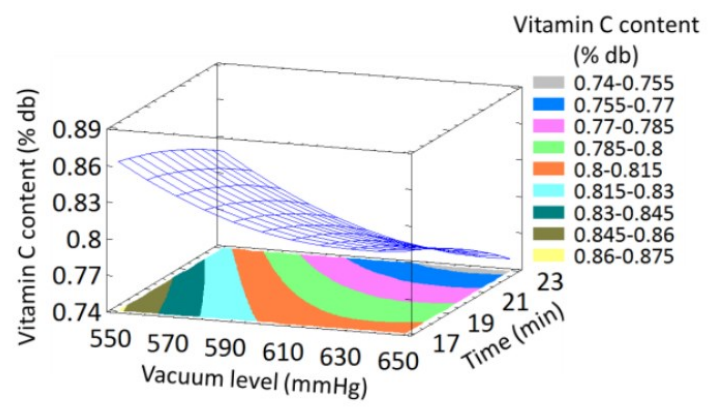

f.

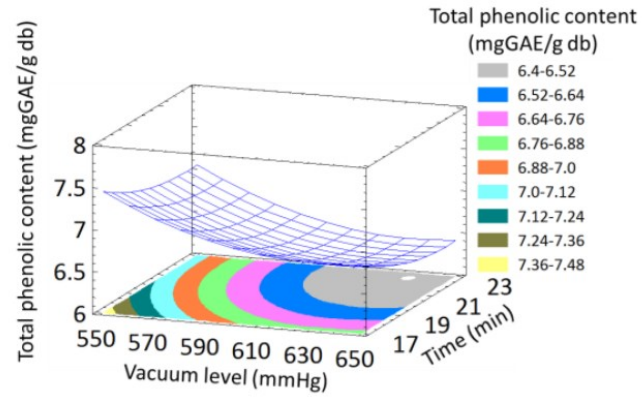

g.

Figure 1. Response surfaces and contour plots for the effects of vacuum level and treatment time on responses. a. Weight gain; $b$. Remaining POD activity; c. Pectin content; d. Anthocyanin content; e. Lycopene content; f. Vitamin C content, and g. Total phenolic content

surface plots an increase in the value of variables of vacuum infiltration led to a reduction in the content of bioactive compounds after blanching, including lycopene, vitamin $\mathrm{C}$ and total phenolic. This was also owing to the rise in thermal conductivity. It may be assumed that heating caused both pigment degradation and an extractability increase due to the breaking of protein-carotenoid complexes: in the skin, the first effect prevailed because of the thinness of tissue, which allowed easy and fast heat conduction; by contrast, in the pulp, the lower temperatures reached allowed the promotion of the breakdown of protein complexes with lycopene, but not its degradation (D'Evoli et al., 2013). The isomerization phenomenon of lycopene during heating was also observed as lycopene presented naturally in the trans form in food products converted into the cis forms (Lee and Chen, 2002). Therefore, there was only a small change in lycopene content. Vitamin C is the least stable of all vitamins and is easily destroyed during thermal processing (Cruz et al., 2008) so that it lost significantly. When tomatoes were subjected to blanching, the total phenolic seemed to decrease slightly. The degree of polyphenol degradation depends very much on the processing time and the size of the 
vegetables. Thermal processing may release more bound phenolic acids from the breakdown of cellular constituents, although disruption of cell walls also releases the oxidative and hydrolytic enzymes that can destroy the antioxidant in fruit and vegetables (Aminah and Permatasari, 2013). Interestingly, however, in this study, because anthocyanin concentrated mainly in the outer skin of black cherry tomatoes, an increase in the rate of heat transfer, which corresponded to an increase in the value of vacuum level and processing time had an insignificant effect on the anthocyanin content after blanching at the same temperature and time.

From the model, optimum conditions of vacuum impregnation of black cherry tomatoes for each response were obtained as presented in Table 4. With three responses chosen, the optimum conditions where all parameters simultaneously meet the desirable criteria could be visualized graphically by superimposing the contours of the response surfaces in an overlay plot (Figure 2). Under the optimum conditions of vacuum level $620.70 \mathrm{mmHg}$ and treatment time $22.27 \mathrm{mins}$, two maximum responses of $2.33 \%$ weight gain and $36.55 \%$ dry-basis $(\mathrm{db})$ pectin content and minimum response of $12.24 \% \mathrm{db}$ remaining peroxidase were predicted. An experiment was carried out applying the above optimum conditions and the data obtained for three indicators of weight gain, remaining peroxidase activity and pectin content were $2.31 \%, 12.44 \% \mathrm{db}$ and $36.24 \% \mathrm{db}$, respectively. This confirmed the agreement of the results achieved from models and experiments.

Table 4. Optimum conditions of vacuum infiltration for each response

\begin{tabular}{|c|c|c|c|}
\hline \multirow[b]{2}{*}{ Response } & \multirow{2}{*}{$\begin{array}{l}\text { Optimum } \\
\text { value }\end{array}$} & \multicolumn{2}{|c|}{ Optimum conditions } \\
\hline & & $\begin{array}{l}\text { Vacuum level } \\
\text { (mmHg) }\end{array}$ & $\begin{array}{l}\text { Treatment } \\
\text { time (min) }\end{array}$ \\
\hline Weight gain (\%) & 2.34 & 637.86 & 21.89 \\
\hline $\begin{array}{l}\text { Remaining } \\
\text { peroxidase activity } \\
(\% \mathrm{db})\end{array}$ & 12.17 & 638.92 & 21.69 \\
\hline $\begin{array}{l}\text { Pectin content } \\
(\% \mathrm{db})\end{array}$ & 36.65 & 641.62 & 22.43 \\
\hline
\end{tabular}

To better understand the effect of vacuum treatment on the improvement of bioactive compounds in fruits after blanching, after the optimum sample was chosen, the study conducted the $2^{\text {nd }}$ control sample (not vacuum treated and blanched at $90^{\circ} \mathrm{C}$ for $80 \mathrm{~s}$ so that the remaining peroxidase activity - $12.51 \% \mathrm{db}$ was equivalent to the value of the optimum sample - $12.24 \%$ $\mathrm{db}$ ) beside the $1^{\text {st }}$ control sample (not vacuum treated and blanched at the same conditions $-90^{\circ} \mathrm{C}, 60 \mathrm{~s}$ ) and compared the quality between three samples (Table 5). Due to the increase in heat transfer capacity during blanching by vacuum infiltration process, the content of lycopene, vitamin $\mathrm{C}$ and total phenolic were all lower in the optimum sample compared to the $1^{\text {st }}$-control sample (no vacuum treatment). However, if compared to the $2^{\text {nd }}$ control sample, it could be seen that the combination of vacuum impregnation before blanching had been proven to improve the nutritional components of fruits.

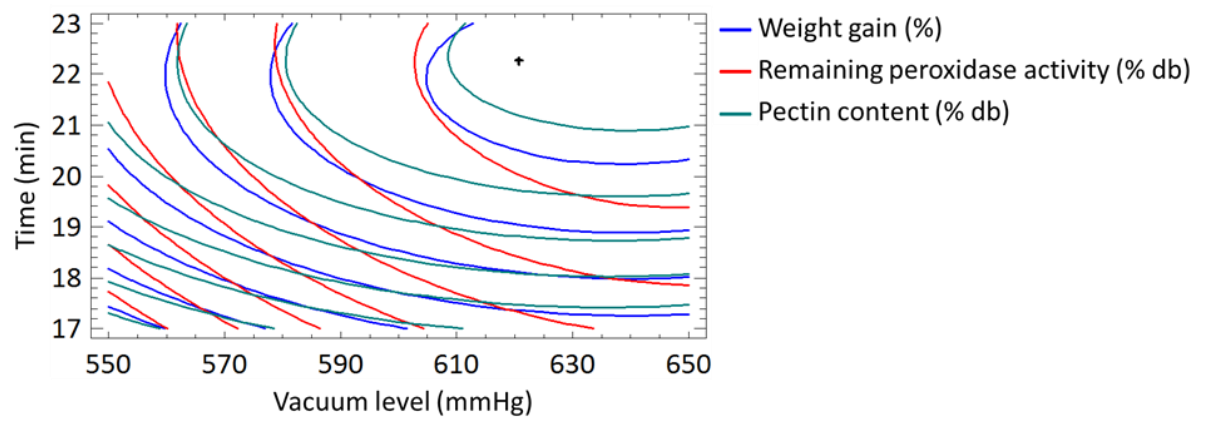

Figure 2. Overlay plot for optimal region

Table 5. Comparison of the parameters of the optimum vacuum treatment sample with two control samples

\begin{tabular}{|c|c|c|c|c|}
\hline \multirow{2}{*}{\multicolumn{2}{|c|}{ Parameters }} & \multicolumn{3}{|c|}{ Sample } \\
\hline & & Optimum & Control 1 & Control 2 \\
\hline \multirow{2}{*}{ Vacuum infiltration conditions } & Vacuum level (mmHg) & 620.7 & & \\
\hline & Time (min) & 22.27 & treatment & treatment \\
\hline \multirow{2}{*}{ Blanching conditions } & Temperature $\left({ }^{\circ} \mathrm{C}\right)$ & 90 & 90 & 90 \\
\hline & Time (s) & 60 & 60 & 80 \\
\hline \multicolumn{2}{|l|}{ Weight gain (\%) } & 2.33 & 0 & 0 \\
\hline \multicolumn{2}{|l|}{ Remaining POD activity ( $\% \mathrm{db})$} & 12.24 & 29.78 & 12.51 \\
\hline \multicolumn{2}{|l|}{ Pectin content $(\% \mathrm{db})$} & 36.55 & 16.86 & 36.09 \\
\hline \multicolumn{2}{|c|}{ Anthocyanin content (mgCE/100 g db) } & 62.7 & 63.69 & 51.34 \\
\hline \multicolumn{2}{|l|}{ Lycopene content (mg/100 g db) } & 66.32 & 73.82 & 62.26 \\
\hline \multicolumn{2}{|l|}{ Vitamin $\mathrm{C}$ content $(\% \mathrm{db})$} & 0.762 & 1.01 & 0.71 \\
\hline \multicolumn{2}{|c|}{ Total phenolic content (mg GAE/g db) } & 6.42 & 6.55 & 5.7 \\
\hline
\end{tabular}


Especially, anthocyanins are synthesized in response to light, so that, they concentrate primarily on the outer skin, which makes the fruit look attractive but not beneficial during processing (Klee, 2013), therefore, it was degraded more in the $2^{\text {nd }}$-control sample with a longer blanching time ( $80 \mathrm{~s})$ than the optimum sample (only blanched in $60 \mathrm{~s}$ ).

\section{Conclusion}

The vacuum impregnation was optimized to improve the effectiveness of subsequent blanching. From the response surface methodology results, the optimum conditions of vacuum level $620.70 \mathrm{mmHg}$ and treatment time 22.27 mins were obtained with the highest values of weight gain $2.33 \%$ and pectin content $36.55 \%$ db and lowest value of remaining peroxidase activity $12.24 \%$ $\mathrm{db}$. The predicted response values were subsequently confirmed by a verification experiment. Under the optimum conditions, the experimental weight gain, remaining peroxidase activity and pectin content $(2.31 \%$, $12.44 \% \mathrm{db}$ and $36.24 \% \mathrm{db}$, respectively) were following the predicted values.

\section{Conflict of interest}

The authors declare no conflict of interest.

\section{References}

Akyol, Ç., Alpas, H. and Bayındırlı, A. (2006). Inactivation of peroxidase and lipoxygenase in carrots, green beans, and green peas by the combination of high hydrostatic pressure and mild heat treatment. European Food Research and Technology, 224(2), 171-176. https:// doi.org/10.1007/s00217-006-0303-3

Alda, L.M., Gogoasa, I., Bordean, D.M., Gergen, I., Alda, S., Moldovan, C., Nita, L. (2009). Lycopene content of tomatoes and tomato products. Journal of Agroalimentary Processes and Technologies, 15(4), 540-542.

Aminah, A. and Permatasari, K.A. (2013). Effect of drying and cooking methods on antioxidant properties of bitter gourd (Momordica charantia). Journal of Tropical Agriculture and Food Science, 41(2), 249-256.

Choi, S.H., Kim, D.S., Kozukue, N., Kim, H.J., Nishitani, Y., Mizuno, M., Levin, C.E. and Friedman, M. (2014). Protein, free amino acid, phenolic, $\beta$-carotene, and lycopene content, and antioxidative and cancer cell inhibitory effects of 12 greenhouse-grown commercial cherry tomato varieties. Journal of Food Composition and Analysis, 34(2), 115-127. https://doi.org/10.1016/ j.jfca.2014.03.005

Cruz, R.M., Vieira, M.C. and Silva, C.L. (2008). Effect of heat and thermosonication treatments on watercress (Nasturtium officinale) vitamin C degradation kinetics. Innovative Food Science and Emerging Technologies, 9(4), 483-488. https:// doi.org/10.1016/j.ifset.2007.10.005

Davis, A.R., Fish, W.W. and Perkins-Veazie, P. (2003). A rapid spectrophotometric method for analyzing lycopene content in tomato and tomato products. Postharvest Biology and Technology, 28(3), 425430. https://doi.org/10.1016/S0925-5214(02)00203$\mathrm{X}$

D'Evoli, L., Lombardi-Boccia, G. and Lucarini, M. (2013). Influence of heat treatments on carotenoid content of cherry tomatoes. Foods, 2(3), 352-363. https://doi.org/10.3390/foods2030352

Fish, W.W., Perkins-Veazie, P. and Collins, J.K. (2002). A quantitative assay for lycopene that utilizes reduced volumes of organic solvents. Journal of Food Composition and Analysis, 15, 309-317. https://doi.org/10.1006/jfca.2002.1069

Ford, N.A. and Erdman, J.W. (2012). Are lycopene metabolites metabolically active?. Acta Biochimica Polonica, 59, 2159. https://doi.org/10.18388/ abp.2012 2159

Goncalves, E.M., Pinheiro, J., Abreu, M., Brandao T.R.S. and Silva, C.L.M. (2007). Modelling the kinetics of peroxidase inactivation, colour and texture changes of pumpkin (Cucurbita maxima L.) during blanching. Journal of Food Engineering, 81 (4), 693-701. https://doi.org/10.1016/ j.jfoodeng.2007.01.011

Guan, X. and Yao, H. (2008). Optimization of Viscozyme L-assisted extraction of oat bran protein using response surface methodology. Food Chemistry, 106(1), 345-351. https://doi.org/10.1016/ j.foodchem.2007.05.041

Ilahy, R., Hdider, C. and Tlili, I. (2009). Bioactive compounds and antioxidant activity of tomato high lycopene content advanced breeding lines. Tunisian Plant Science and Biotechnology I. The African Journal of Plant Science and Biotechnology, 3 (Special Issue 1), 1-6.

Kaur, H., Chauhan, S. and Sandhir, R. (2011). Protective effect of lycopene on oxidative stress and cognitive decline in the rotenone-induced model of Parkinson's disease. Neurochemical Research, 36(8), 1435-1443. https://doi.org/10.1007/s11064-011-0469-3

Klee, H.J. (2013). Purple tomatoes: longer-lasting, less disease, and better for you. Current Biology, 23(12), R520-R521. https://doi.org/10.1016/ j.cub.2013.05.010 
Lam T.B., Nguyet T.N.M. and Thu D.T.N. (2004). Food Biochemistry Experiment. Vietnam: Vietnam National University Ho Chi Minh City.

Lee, J., Durst, R.W. and Wrolstad, R.E (2005). Determination of total monomeric anthocyanin pigment content of fruit juices, beverages, natural colourants, and wines by the $\mathrm{pH}$ differential method: collaborative study. Journal of AOAC International, 88(5), 1269-1278. https://doi.org/10.1093/ jaoac/88.5.1269

Lee, M.T. and Chen, B.H. (2002). Stability of lycopene during heating and illumination in a model system. Food Chemistry, 78(4), 425-432. https:// doi.org/10.1016/S0308-8146(02)00146-2

Li, H., Deng, Z., Liu, R., Young, J.C., Zhu, H., Loewen, S. and Tsao, R. (2011). Characterization of phytochemicals and antioxidant activities of a purple tomato (Solanum lycopersicum L.). Journal of Agricultural and Food Chemistry, 59(21), 1180311811. https://doi.org/10.1021/jf202364v

Lila, M.A. (2004). Anthocyanins and human health: an in vitro investigative approach. Journal of Biomedicine and Biotechnology, 2004, 306-313. https://doi.org/10.1155/S111072430440401X

Mai, L.T (Ed.). (2005). Methods of Fermentation Technology Analysis. Vietnam: Ha Noi Scientific and Technical Publishing.

Martínez-Monzó, J., Barat, J.M., González-Martínez, C., Chiralt, A. and Fito, P. (2000). Changes in thermal properties of the apple due to vacuum impregnation. Journal of Food Engineering, 43(4), 213-218. https://doi.org/10.1016/S0260-8774(99)00152-1

Mes, P.J., Boches, P., Myers, J.R. and Durst, R. (2008). Characterization of tomatoes expressing anthocyanin in the fruit. Journal of the American Society for Horticultural Science, 133(2), 262-269. https:// doi.org/10.21273/JASHS.133.2.262

Mesbahi, G., Jamalian, J. and Farahnaky, A. (2005). A comparative study on functional properties of beet and citrus pectins in food systems. Food Hydrocolloids, 19(4), 731-738. https:// doi.org/10.1016/j.foodhyd.2004.08.002

Min, J.Y. and Min, K.B. (2014). Serum lycopene, lutein and zeaxanthin, and the risk of Alzheimer's disease mortality in older adults. Dementia and geriatric cognitive disorders, 37(3-4), 246-256. https:// doi.org/10.1159/000356486

Morales-Blancas, E.F., Chandia V.E. and CisnerosZevallos, L. (2002). Thermal inactivation kinetics of peroxidase and lipoxygenase from broccoli, green asparagus and carrots. Journal of Food Science, 67 (1), 146-154. https://doi.org/10.1111/j.13652621.2002.tb11375.x
Mordente, A., Guantario, B., Meucci, E., Silvestrini, A., Lombardi, E., Martorana, G., Giardina, B. and Bohm, V. (2011). Lycopene and cardiovascular diseases: an update. Current Medicinal Chemistry, 18(8), 1146-1163. https:// doi.org/10.2174/092986711795029717

Mujica-Paz, H., Valdez-Fragoso, A., López-Malo, A., Palou, E. and Welti-Chanes, J. (2003). Impregnation properties of some fruits at vacuum pressure. Journal of Food Engineering, 56(4), 307314. https://doi.org/10.1016/S0260-8774(02)00155-3

Ramos-Aguilar, O.P., de Jesús Ornelas-Paz, J., RuizCruz, S., Zamudio-Flores, P.B., Cervantes-Paz, B., Gardea-Béjar, A.A., Pérez-Martínez, J.D., IbarraJunquera, V. and Reyes-Hernández, J. (2015). Effect of ripening and heat processing on the physicochemical and rheological properties of pepper pectins. Carbohydrate Polymers, 115, 112121. https://doi.org/10.1016/j.carbpol.2014.08.062

Saurel, R. (2002). The use of vacuum technology to improve processed fruit and vegetables. In Jongen, W. (Ed.). Fruit and Vegetable Processing. Abington Cambridge, England: Woodhead Publishing Limited. https://doi.org/10.1201/9781439823187.ch18

Teixeira, B., Marques, A., Ramos, C., Serrano, C., Matos, O., Neng, N.R., Nogueira, J.M.F., Saraiva J.A. and Nunes, M.L. (2013). Chemical composition and bioactivity of different oregano (Origanum vulgare) extracts and essential oil. Journal of the Science of Food and Agriculture, 93(11), 2707-2714. https://doi.org/10.1002/jsfa.6089

Xiao, H.W., Bai, J.W., Sun, D.W. and Gao, Z.J. (2014). The application of superheated steam impingement blanching (SSIB) in agricultural products processing -A review. Journal of Food Engineering, 132, 3947. https://doi.org/10.1016/j.jfoodeng.2014.01.032

Zabeti, M., Daud, W.M.A.W. and Aroua, M.K. (2009). Optimization of the activity of $\mathrm{CaO} / \mathrm{Al} 2 \mathrm{O} 3$ catalyst for biodiesel production using response surface methodology. Applied Catalysis A: General, 366(1), 154-159.

https://doi.org/10.1016/ j.apcata.2009.06.047

Zhang, W., Xie, F., Lan, X., Gong, S. and Wang, Z. (2018). Characteristics of pectin from black cherry tomato waste modified by dynamic high-pressure microfluidization. Journal of Food Engineering, 216, 90-97. https://doi.org/10.1016/ j.jfoodeng.2017.07.032

Zhao, Y. and Xie, J. (2004). Practical applications of vacuum impregnation in fruit and vegetable processing. Trends in Food Science and Technology, 15(9), 434-451. https://doi.org/10.1016/ j.tifs. 2004.01 .008 